\title{
Follow-up of a case of subacute thyroiditis with uncommon thyroid ${ }^{99 m}$ Tc uptake
}

\author{
Acompanhamento de caso de tiroidite subaguda \\ com absorção incomum de ${ }^{99 m}$ Tc pela tiroide
}

Zhe Zhang', Chengjiang Li'

'Department of Endocrinology and Metabolism, The First Affiliated Hospital of Medical College of Zhejiang University, Hangzhou, China

\author{
Correspondence to: \\ Zhe Zhang \\ 79\# Qinchun Road, Hangzhou, \\ Zhejiang Province, China \\ 10518093zz@163.com \\ Received on Sept/18/2012 \\ Accepted on Nov/5/2012
}

\begin{abstract}
SUMMARY
Thyroidal ${ }^{99 m}$ Tc uptake in the acute thyrotoxic phase of subacute thyroiditis (SAT) is always inhibited. However, a patient with SAT had signs in the right-side thyroid gland with transient thyrotoxicosis and

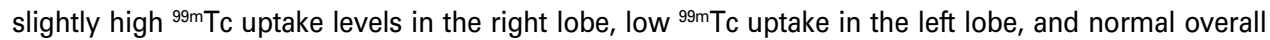
uptake. Histological examination showed cellular destruction and granulomatous inflammatory changes in the right lobe, with marked interstitial fibrosis in the left lobe. The patient was thyrotrophin-receptor antibody (TRAb) positive. After a short course of prednisolone, SAT-like symptoms and signs improved. TRAb-positivity resolved spontaneously after 22 months, andTSH levels were slightly low for 22 months. Levels then kept normal in the following four years. In conclusion, high ${ }^{99 \mathrm{~m} T c}$ uptake by the right lobe was due to the combined effects ofTRAb and left thyroid gland fibrosis. Arq Bras Endocrinol Metab. 2013;57(8):659-62
\end{abstract}

\section{SUMÁRIO}

A absorção tiroidiana de ${ }^{99 m}$ Tc no estado tirotóxico agudo da tireoidite subaguda (SAT) é sempre inibida. Entretanto, um paciente com SAT apresentou sinais na tiroide direita, com tirotoxicose transitória e níveis levemente elevados de ${ }^{99 \mathrm{~m} T c}$ no lobo direito, baixa absorção de ${ }^{99 \mathrm{~m}} \mathrm{Tc}$ no lobo esquerdo e absorção geral normal. $\mathrm{O}$ exame histológico mostrou destruição celular e alterações inflamatórias granulomatosas no lobo direito, com fibrose intersticial marcada no lobo esquerdo. 0 paciente foi positivo para anticorpos antirreceptores da tireotropina (TRAb). Após um curto tratamento com prednisolona, os sintomas e sinais da SAT melhoraram. A positividade paraTRAb foi resolvida espontaneamente em 22 meses. Os níveis deTSH permaneceram levemente baixos por 22 meses e, depois, se mantiveram normais nos quatro anos seguintes. Concluiu-se que a alta absorção de ${ }^{99 \mathrm{~m}} \mathrm{Tc}$ pelo lobo direito foi devida à combinação entreTRAb e fibrose da tiroide esquerda. Arq Bras Endocrinol Metab. 2013;57(8):659-62

\section{INTRODUCTION}

$\mathrm{I}$ $\mathrm{t}$ is generally known that the uptake of radioactive technetium $\left({ }^{99 \mathrm{~m}} \mathrm{Tc}\right)$ or radioactive iodine by the thyroid is markedly diminished in the thyrotoxic stage of subacute thyroiditis (SAT), as numerous thyroidal follicles are destroyed, and large amounts of thyroid hormones are released, inhibiting TSH levels. We report here a case of a patient who had normal levels of total ${ }^{99 \mathrm{~m}} \mathrm{Tc}$ uptake in the acute SAT phase; the level of ${ }^{99 \mathrm{~m}} \mathrm{Tc}$ uptake increased slightly in the right-side painful thyroid gland, and decreased in left painless thyroid gland. This phenomenon is very rare and the underlying cause is not clear.

In recent years, high titers of thyrotropin-receptor antibody (TRAb) or thyroid-stimulating antibody (TSAb) were found during the course or after SAT (1-3). The elevated or normal ${ }^{99 \mathrm{~m}} \mathrm{Tc}$ uptake in the course of SAT has been associated with the detection of TRAb and TSAb (4-7). However, in the present case, some parts of gland, and not the whole gland, showed high ${ }^{99 \mathrm{~m}} \mathrm{Tc}$ uptake at diagnosis of SAT. Therefore, in order to discuss the possible pathogenic mechanisms that occur during the course of this disease, we investigated the histology of the thyroid gland in this patient and detected TRAb.

\section{CASE REPORT}

On May $12^{\text {th }}, 2006$, a 44-year-old man came to our clinic complaining of high fever $\left(39.0^{\circ} \mathrm{C}\right)$ with severe right-side neck pain, right shoulder pain, weight loss of $2 \mathrm{~kg}$, and finger tremors for the previous week. One month before, he had suffered from an upper respiratory tract infection. Physical examination showed that his blood pressure was $110 / 72 \mathrm{mmHg}$ and pulse rate was $80 \mathrm{bpm}$ and regular. The right lobe of the thyroid gland was slightly enlarged, firm and tender. The left lobe of the thyroid was not palpable and was painless. There were 
no signs of Graves' ophthalmopathy. No other clinically relevant physical findings were recorded. Laboratory findings showed the following result: blood white cells, 7.9 x 109/ $\mathrm{mm}^{3}$; ESR, $66 \mathrm{~mm} / \mathrm{h}$; C-reactive protein (CRP), $20.2 \mathrm{mg} / \mathrm{dL}$. His thyroid function was as follows: free thyroxine (fT4), 77.2 ng/dL (10.3-24.45 ng/dL); free tri-iodothyronine (fT3), $19.4 \mathrm{pg} / \mathrm{mL}(3.1-6.8 \mathrm{pg} / \mathrm{mL})$; TSH, $0.017 \mu \mathrm{lU} / \mathrm{mL}(0.4-4.0 \mu \mathrm{lU} / \mathrm{mL})$; anti-thyroid peroxidase antibodies (TPOAb), $10.4 \mathrm{U} / \mathrm{mL}(<34 \mathrm{U} /$ $\mathrm{mL})$. Serum levels of fT4, fT3, TSH, and TPOAb were measured by chemiluminescence (DPC TIANJIN Co. Ltd.). Serum IgG antibodies to Epstein-Barr virus were positive; other serum antibodies to cytomegalovirus, $\mathrm{CO}^{-}$ xsackievirus, and influenza were negative.

Ultrasonography of the thyroid gland showed slightly enlarged goiter in the right lobe (left: $4.1 \times 1.5 \mathrm{x}$ 1.9; right: $4.4 \times 2.5 \times 2.9 \mathrm{~cm}$ ) and hypoechoic lesions in both lobes. Normal ${ }^{99 \mathrm{~m}} \mathrm{Tc}$ uptake levels $(2.43 \%$ at 30 $\mathrm{m}$; normal range 0.24-3.34\%) were observed. However, ${ }^{99 \mathrm{~m}} \mathrm{Tc}$ uptake in the right lobe was greater than in the left lobe $(2.01 \%$ vs. $0.44 \%$ at $30 \mathrm{~min})$, which was higher than the normal range $(0.12-1.67 \%$ at $30 \mathrm{~min})$. Histological examination of needle biopsy specimens obtained from both right and left lobes showed small thyroid follicles with little colloid, eosinophilic degeneration of epithelial cells, and marked interstitial fibrosis in the left lobe, with destruction of thyroid follicles, small lymphocytes, macrophages and granulomatous inflammatory changes in the right lobe (Figures 1A, B, C).

Treatment with a 30-mg daily dose of prednisolone was commenced on May 22 $2^{\text {nd }}, 2006$. Over the following two days, the patient's fever and tenderness in the right thyroid lobe resolved. CRP concentration was normal $(9.86 \mathrm{mg} / \mathrm{dL})$ on May $25^{\text {th }}$. ESR was also normal (18 $\mathrm{mm} / \mathrm{h}$ ) on May $30^{\text {th }}$. We gradually reduced the dose of prednisolone from May 31 $1^{\text {st }}, 2006$ and stopped this drug on July $16^{\text {th }}$. During the course of prednisolone taper, CRP and ESR remained within normal levels, and goiter size gradually decreased. Ultrasonography of the thyroid gland on July $25^{\text {th }}, 2006$ also showed that goiter size was decreased compared with before treatment measurements (left: $4.1 \times 1.5 \times 1.8 \mathrm{~cm}$; right: $4.0 \times 2.0 \times 1.6 \mathrm{~cm}$ ) and hypoechoic lesions disappeared, but there were diffused echoic changes in both lobes. The results of the total ${ }^{99 \mathrm{~m}} \mathrm{Tc}$ uptake on July $30^{\text {th }}, 2006$ were slightly elevated $(4.15 \%: 3.14 \%$ in the right lobe and $1.01 \%$ in the left lobe). The level of fT4 and fT3 returned to normal levels on August $2^{\text {nd }}, 2006$ and September $5^{\text {th }}, 2006$. The levels of serum
TSH were suppressed for a longer period and only returned to normal levels by March $28^{\text {th }}, 2008$. The patient's serum levels of fT4, fT3, and TSH remained normal for the subsequent 6 months (detected on October $\left.14^{\text {th }}, 2008\right)$. During the course of this disease, the patient refused any anti-thyroid drugs, as he was concerned about their side effects and his symptoms of thyrotoxicosis were minimal.

During the course of the disease, anti-thyroid peroxidase antibodies (TPOAb) remained negative, but TRAb antibodies were detected on August $2^{\text {nd }}, 2006$. These were negative by March $28^{\text {th }}, 2008$. Changes in thyroid function and thyroid-related autoimmune antibody levels are shown in table 1 .
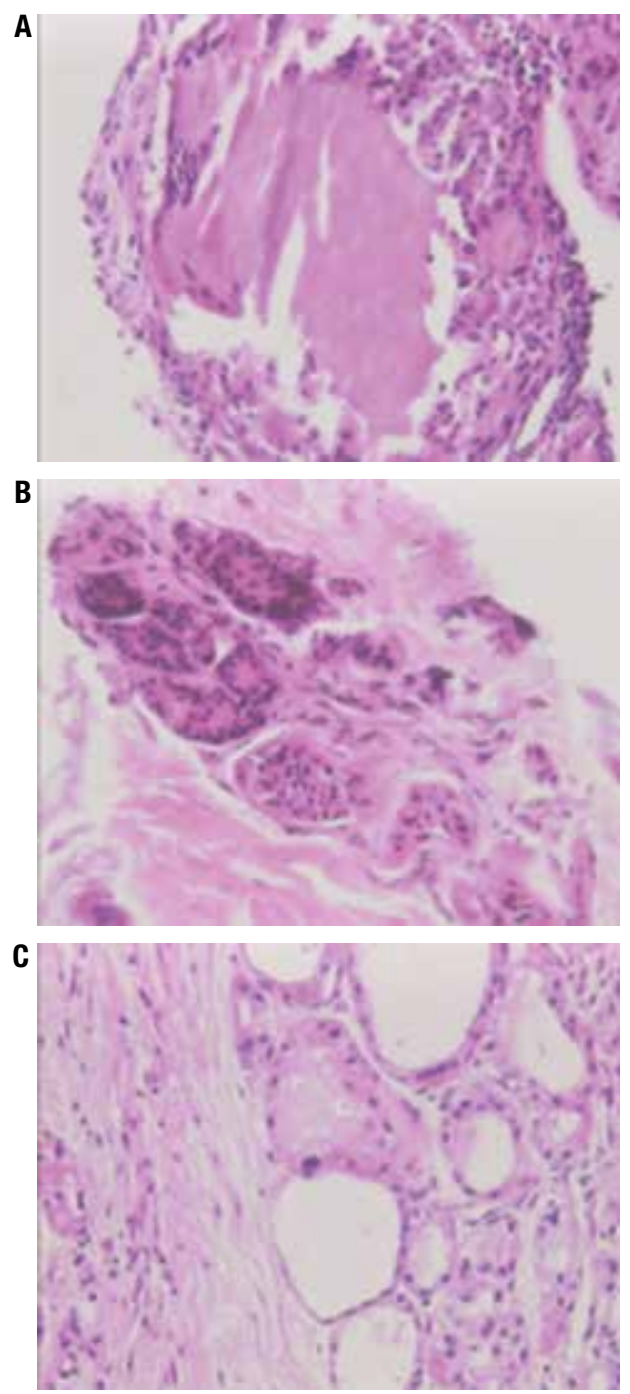

Figure 1. Histological examination of the thyroid gland. (A) Histological examination of the right-side thyroid gland revealed destruction of thyroid follicles (HE stain, X400). (B) Giant cells were present in the right side of the thyroid gland (HE stain, $x 400$ ). (C) Histological examination of the left thyroid gland shows small follicle with little colloid, eosinophilic degeneration of the epithelial cells, and interstitial fibrosis (HE stain, x400). 
Table 1. Clinical course of laboratory findings

\begin{tabular}{|c|c|c|c|c|c|c|c|c|c|c|}
\hline $\begin{array}{c}\text { DATE } \\
\text { Normal range } \\
\end{array}$ & $\begin{array}{c}\text { FT4 } \\
12-22 \mathrm{ng} / \mathrm{dL} \\
\end{array}$ & $\begin{array}{c}\mathrm{FT} 3 \\
3.1-6.8 \mathrm{pg} / \mathrm{mL} \\
\end{array}$ & $\begin{array}{c}\text { STSH } \\
0.27-4.2 \text { ulU/mL } \\
\end{array}$ & $\begin{array}{l}\text { TPOAB } \\
\mathbf{0 - 3 4 \%} \\
\end{array}$ & TRAB & $\begin{array}{c}\text { ECT } \\
0.24-3.34 \% \\
\end{array}$ & $\begin{array}{l}\text { ECT of } \\
\text { left \% } \\
\end{array}$ & $\begin{array}{l}\text { ECT of } \\
\text { right \% }\end{array}$ & $\begin{array}{c}\text { CRP } \\
0-10 \mathrm{mg} / \mathrm{dL} \\
\end{array}$ & $\begin{array}{c}\text { ESR } \\
0-20 \mathrm{~mm} / \mathrm{h} \\
\end{array}$ \\
\hline May15 ${ }^{\text {th }}, 2006$ & 77.2 & 19.4 & 0.017 & 10.4 & & & & & 27.8 & 66 \\
\hline May $19^{\text {th }}$ & & & & & & 2.43 & 0.44 & 2.01 & & \\
\hline May $2^{\text {nd }}$ & 53.1 & 12.3 & 0.022 & 10.0 & + & & & & & \\
\hline May $25^{\text {th }}$ & & & & & & & & & 9.86 & 55 \\
\hline May $30^{\text {th }}$ & & & & & & & & & & 18 \\
\hline June $2^{\text {nd }}$ & 46.7 & 7.98 & 0.005 & 22.8 & & & & & & \\
\hline June $17^{\text {th }}$ & 39.2 & 7.59 & 0.013 & & & & & & & \\
\hline June $28^{\text {th }}$ & 38.59 & 30.21 & 0.005 & 28.23 & & & & & & 5 \\
\hline July $12^{\text {th }}$ & 40 & 10.3 & 0.004 & 18.9 & & 4.15 & 1.01 & 3.17 & 2.32 & 7 \\
\hline Aug $2^{\text {nd }}$ & 15.51 & 7.52 & 0.004 & & + & & & & & \\
\hline $\operatorname{Sep} 5^{\text {th }}$ & 12.27 & 4.12 & 0.03 & 14.33 & & & & & & \\
\hline Feb16 $^{\text {th }}, 2007$ & 21.13 & 6.13 & 0.02 & 9.79 & + & & & & & \\
\hline Aug $8^{\text {th }}$ & 19.16 & 3.82 & 0.02 & 9.42 & + & & & & & \\
\hline Mar28 $8^{\text {th }}, 2008$ & 18.11 & 4.52 & 1.34 & 7.14 & - & & & & & \\
\hline Aug14 $4^{\text {th }}$ & 19.25 & 4.17 & 2.06 & 9.30 & _ & & & & & \\
\hline
\end{tabular}

ESR: erythrocyte sedimentation rate; CRP: C-reactive protein; fT4: free thyroxin; fT3: free tri-iodothyronine; TSH: thyrotropin; TRAb: thyrotropin-receptor antibody; TPOAb: anti-thyroid peroxidase antibodies.

After Aug $2^{\text {nd }}$, 2006, normal ranges changed as follows: fT4: 10.3-24.45 pg/dL; fT3: 3.23-7.22 ng/mL; sTSH: 0.4-4.0 ulU/L; TpoAb: 0-35\%, because this patient was followed up at the local hospital.

\section{DISCUSSION}

According to Iitaka's criteria for SAT (8), our patient was diagnosed with SAT on the basis of the following findings: 1) thyroid was enlarged and tender with associated fever; 2) ESR level was increased, but without leukocytosis; 3) histological examination of needle biopsy specimens showed granulomatous inflammatory changes; 4) the patient had symptoms and signs of transient hyperthyroxinemia; 5 ) prednisolone was effective; and 6 ) the function and TRAb levels recovered without any anti-thyroid medications.

However, several discrepancies exist regarding this diagnosis. Firstly, thyroidal ${ }^{99 \mathrm{~m}} \mathrm{Tc}$ uptake in the thyrotoxic phase was not suppressed. This phenomenon is rare. The uptake of ${ }^{99 \mathrm{~m}} \mathrm{Tc}$ commonly decreased in the thyrotoxic phase, as large amounts of the gland are destroyed and TSH production is suppressed. When the illness is mild, normal thyroid tissue can compensate for the loss of function of the affected tissue. Therefore, thyroid function remains normal without decreased TSH levels and ${ }^{99 \mathrm{~m}} \mathrm{Tc}$ uptake level can be normal. However, the patient in this case had high levels of thyroid hormones, low levels of TSH and severe symptoms and, therefore, we could not explain the normal uptake of ${ }^{99} \mathrm{~m}$ Tc during thyrotoxic phase with a mild illness profile.

Second, the duration of the thyrotoxic phase was 22 months, which was longer than that of typical patients, without transient hypothyroidism. Transient thyrotoxicosis in SAT results from the uncontrolled leakage of thyroxine from the inflamed gland. After 2 to 8 weeks, when the supply of stored hormone is exhausted, thyrotoxicosis resolves spontaneously. Hypothyroidism ensues as the biosynthetic capabilities of the thyroid continue to be impaired. However, this is also transient, and can last for approximately 1 month, with the subsequent restoration of normal thyroid function in most patients. Therefore, the long duration of thyrotoxicosis without hypothyroidism in our patient cannot be explained by the normal pathophysiology of SAT.

Third, the patient had positive TRAb. In general, positive TRAb is used to diagnose Graves' disease. However, in recent studies, we found serum TRAb positive in $10 \%$ patients with SAT $(9,10)$. TRAb titers were very high in several patients (10). Iitaka and cols. (8) found that patients who appeared positive for TRAb after SAT had genetic background predisposing to Graves' disease. This finding may explain why only $10 \%$ SAT may produce TRAb.

The possible mechanisms of TRAb production were listed as follows. Fujii and cols. (5) stated that when the thyroid gland is impaired, the TSH receptor (TSHR) is released into the blood, which induces autoimmune reactivity to produce TRAb. On the one hand, inflammation affects the immune surveillance system, resulting in autoantibody production. On the other hand, inflammatory and destructive changes seem to influence the degradation of TRAb. In addition, virus also can induce positive TRAb. Virus infection incites 
SAT. Some viruses that have molecular structure similar to that of TSH receptors induce expression of MHC II, which leads to autoimmune reaction resulting in positive TRAb. In some reports $(5,7)$, TRAb also became spontaneously negative with improvement in the SAT, because the immune surveillance system may recover with time. In our patient, positive TRAb status remained for 22 months, and then disappeared spontaneously while TSH levels simultaneously returned to normal. Thyrotoxicosis can resolve spontaneously without the use of anti-thyroid drugs. This supports the viewpoint that the production of TRAb is transient. TRAb positivity could also explain the normal ${ }^{99 \mathrm{~m}} \mathrm{Tc}$ uptake found during the thyrotoxic phase. In this patient, the recovery time of TRAb was consistent with time to TSH recovery and, therefore, TRAb could have caused the long duration thyrotoxicosis.

Some patients with SAT have been reported to have circulating TRAb following Grave's disease, as histological examinations confirmed the typical changes of Graves' disease: diffuse hypertrophy and hyperplasia of thyroid follicles, which have a columnar and folded epithelium and little colloid, and therapy with anti-thyroid drugs was effective $(11,12)$. However, in our patient, there was no histological evidence of Grave's disease. Histological examination revealed destruction of thyroid follicles, granuloma formation in the right thyroid, small thyroid follicles with little colloid, and marked interstitial fibrosis in the left thyroid gland.

We remain uncertain as to the cause of small follicles and interstitial fibrosis in the left thyroid gland. Hashimoto's disease was excluded, as there was no histological indication of destructive Hashimoto's disease or a hypothyroid state after therapy. At the same time, serum titers of TgAb and TPOAb were both negative. These histological changes may have been caused by SAT, as different degrees of SAT progression can occur in different locations of the thyroid gland. The right side of the gland was in the acute phase of SAT when the patient was diagnosed, while the left gland could have been in the recovery phase. Ultrasonography of the thyroid gland showed hypoechoic lesions in both lobes, at first. After treatment, hypoechoic lesions in left lobe disappeared. This finding supports the diagnosis of SAT in left thyroid lobe. However, this theory is unlikely, as the patient did not have any previous symptoms or signs in the left thyroid gland. However, painless SAT has been confirmed by histological examination $(13,14)$. Regardless of the etiology, small folli- cles and interstitial fibrosis of the left lobe could explain why the uptake of ${ }^{99 \mathrm{~m}} \mathrm{Tc}$ in the painful right-side lobe was greater than the painless left-side lobe, after corrections were made for the weight of the gland.

In conclusion, we consider that the high ${ }^{99 \mathrm{~m}} \mathrm{Tc}$ uptake in the right thyroid lobe in this patient was due to the presence of both the TRAb and the small follicles and interstitial fibrosis of left thyroid gland. We feel that there is a need to study why TRAb, rather than another autoimmune antibody, is produced in patients with SAT.

Acknowledgements: the study was supported by the Natural Science Foundation of Zhejiang Province of China, $\mathrm{N}^{\circ}$ : Y2090448.

Disclosure: no potential conflict of interest relevant to this article was reported.

\section{REFERENCES}

1. Mitani Y, Shigemasa C, Kouchi T, Taniguchi S, Ueta Y, Yoshida A, et al. Detection of thyroid-stimulating antibody in patients with inflammatory thyrotoxicosis. Horm Res. 1992;37:196-201.

2. Nakamura S, Saio Y, Suzuki E. Subacute thyroiditis with thyroidstimulation blocking antibodies: a case report. Endocr J. 1996;43:185-9.

3. litaka M, Kakinuma S, Yamanaka K, Fujimaki S, Oosuga I, Wada S, et al. Induction of autoimmune hypothyroidism and subsequent hyperthyroidism by TSH receptor antibodies following subacute thyroiditis: a case report. Endocr J. 2001;48:139-42.

4. Hoang TD, Mai VQ, Clyde PW, Shakir MK. Simultaneous occurrence of subacute thyroiditis and Graves' disease. Thyroid. 2011;21:1397-400.

5. Fujii S, Miwa U, Seta T, Ohoka Tand, Mizukami Y. Subacute thyroiditis with highly positive thyrotropin receptor antibodies and high thyroidal active iodine uptake. Inter Med. 2003;42:704-9.

6. Nakamura S, Saio Y, Ishimori M. A case of Graves' disease associated with painful thyroiditis. Endocr J. 1997;44:611-6.

7. Lu Y, Jieyi W, Li Z. Subacute thyroiditis combined with Graves' disease. Chinese J Pract Inter Medicine. 2009;29:129-30.

8. litaka M, Momotani N, HisaokaT, Noh JJ, Ishikawe N, Ishii J, et al. TSH receptor antibody-associated thyroid dysfunction following subacute thyroiditis. Clin Endocrinol (Oxf). 1998;48:445-53.

9. Kamijo K. TSH-receptor antibody measurement in patients with various thyrotoxicosis and Hashimoto's thyroiditis: a comparison of two-step assays, coated plate ELISA using porcine TSHReceptor and coated tube radioassay using human recombinant TSH-receptor. Endocr J. 2003;50:113-6.

10. Ningling W, Zhaohui L, Jing D, Guoqing $Y$, Jianming B, Jingtao D, et al. Significance of thyrotrophic receptor antibody (TRAb) in clinical diagnosis of Graves' disease. Med J Chin PLA. 2011;36:501-4.

11. Zhou R, Pang CP, Chen HZ. Thyroid uptake is rised in a patient with subacute thyroiditis. CJEM. 2005;21:575.

12. Shigemasa $C$, Teshima S, Taniguchi S, Ueta Y, Mitani Y, Yoshida A. Pertechnetate thyroid uptake is not always suppressed in patients with subacute thyroiditis. Clin Nucl Med. 1997;22:109-14.

13. Daniels $\mathrm{GH}$. Atypical subacute thyroiditis: preliminary observations. Thyroid. 2001;11:691-5.

14. Tsai CH, Lee JJ, Liu CL, Tzen CY, Cheng SP. Atypical subacute thyroiditis. Surgery. 2010;147:461-2. 